\title{
Biochemical markers of cerebrovascular injury in sleep apnoea syndrome
}

\author{
W. Jordan*, J. Hagedohm*, J. Wiltfang*, G. Laier-Groeneveld", H. Tumani ${ }^{\star}$, A. Rodenbeck*, \\ E. Rüther*, G. Hajak*
}

Biochemical markers of cerebrovascular injury in sleep apnoea syndrome. W. Jordan, J. Hagedohm, J. Wiltfang, G. Laier-Groeneveld, H. Tumani, A. Rodenbeck, E. Rüther, G. Hajak. C ERS Journals Ltd 2002.

ABSTRACT: Sleep apnoea syndrome (SAS) is a known risk factor for vascular diseases and stroke. Structural brain damage, manifesting as an overt neurological deficit or more subtly as cognitive dysfunction, is a frequent symptom in SAS. The presence of a biochemical marker of cerebral injury would be of great benefit in SAS to screen for even small brain damage and to monitor efficiacy of therapy.

Therefore, in 10 patients with mild SAS (age 50.8 \pm 9.9 yrs, respiratory disturbance index (RDI) $18 \pm 3.6$, lowest arterial oxygen saturation $\left(\min S_{\mathrm{a}}, \mathrm{O}_{2}\right) 80.5 \pm 4.06 \%$ ) and nine patients with severe SAS (age 50.3 $\pm 11.5 \mathrm{yrs}$, RDI $75.4 \pm 21.7$, min $\mathrm{Sa}_{\mathrm{a}} \mathrm{O}_{2}$ $56.56 \pm 14.58 \%$ ), serum concentrations of neuron-specific enolase (NSE), S-100 $\beta$ protein, and $\beta$-trace were measured just before and after sleep using commercially available assays.

Only serum levels in the normal range could be found, independent of when the blood was taken or the degree of SAS.

Structural cerebral injury caused by sleep apnoea syndrome in patients without neurological symptoms or previous cerebrovascular events may be too small to produce a measurable increase in $\mathrm{S}-100 \beta$, neuron-specific enolase and $\beta$-trace serum concentrations or subclinical cerebral damage may be outside the lower detection limits of the analytical methods which were used. There is a need for biochemical markers and more sensitive methods for detecting small cerebral injury in sleep apnoea syndrome. Eur Respir J 2002; 20: 158-164.

\begin{abstract}
*Dept of Psychiatry and Psychotherapy, University Göttingen, Göttingen, \#Dept of Pulmology, Evangelic Hospital Göttingen-Weende, Bovenden and Dept of Neurology of the University Ulm, Ulm, Germany.
\end{abstract}

Correspondence: W. Jordan, Psychiatrische Klinik, Universität Gôttingen, Von Sieboldstr. 5, 37075 Gôttingen, Germany.

Fax: 49551393887

E-mail: wjordan@gwg.de

Keywords: Biochemical marker

$\beta$-trace

neuron-specific enolase

sleep apnoea syndrome

stroke

S- $100 \beta$

Received: June 202001

Accepted after revision: February 11 2002
Sleep apnoea syndrome (SAS) is characterised by recurrent disturbances of breathing during sleep with repetitive hypopnoeic and apnoeic phases as well as snoring, due to intermittent narrowing or occlusion of the upper airway. Besides an increased prevalence of cardiovascular complications, thromboembolic and haemodynamic events with consecutive ischemic stroke are possible consequences of SAS [1], and cerebral ischaemia is one of the major risks for patients with SAS [2].

Structural brain damage, manifesting as overt neurological deficit or subtle neuropsychological dysfunction, is a frequent symptom of SAS [3]. Although the anatomical and functional extent of stroke can be readily determined through clinical examination and radiological imaging techniques, most of the brain is intellectually silent, and there are inherent difficulties with the detection of more subtle forms of cerebral injury such as cognitive deficit. The battery of neuropsychological tests employed on a research basis require specialist staff to perform them, are protracted and inappropriate for clinical practice. Therefore the presence of a biochemical marker of cerebral injury would be of great benefit in SAS.

Several monitoring techniques have been developed based on measuring levels of various proteins, including neuron-specific enolase (NSE), creatine kinase BB, myelin basic protein, glial fibrillary acidic protein, interleukin-6, transforming growth factor- $\beta$, and S-100 $\beta$ protein [4-9]. However, in most studies these substances can only be measured in the cerebrospinal fluid (CSF) [10], and collecting CSF samples by lumbar puncture is only indicated for diagnostic purposes in severe cases and is associated with a risk of complications. Contamination due to the sampling procedure may also affect the concentration of all markers in CSF [11]. Therefore, potential noninvasive serum markers reflecting minor ischemic injury have attracted attention. A technique to measure blood levels of protein markers of cerebrovascular stress or brain injury could allow frequent testing at relatively low risk and thus be useful in SAS for estimating the possible extent of brain damage, detecting high-risk patients for stroke, selecting such patients for more aggressive treatment and monitoring efficiacy of therapy.

Plasma adenosine has been used previously in SAS patients as a marker of hypoxaemia [12] and was later also found to be a sensitive indicator of cerebral ischaemia during carotid endarterectomy [13]. However, no correlation was found between adenosine 
levels and focal brain damage, and the vasodilatory effects of adenosine might also be involved in apnoearelated fluctuations of cerebral blood flow. In addition, methodological difficulties limited its use in routine clinical practice. Other biochemical markers of hypoxaemia or indices of oxygen radical reactions like bilirubin [14] or cyclic guanosine monophosphate [15] may be too unspecific for cerebral injury or be directly affected by SAS associated disturbances such as right-sided heart failure or renal dysfunction [15]. Currently, measurement of S-100 $\beta$ protein and NSE in blood are reported to be the most suitable noninvasive methods [16].

The term "S-100" describes a family of dimeric proteins consisting of two subunits, called $\alpha$ and $\beta$. Three isoforms are known. S-100a $(\alpha \beta)$ is present in glial cells and melanocytes, and $S-100 b(\beta \beta)$ is found in high concentrations in glial cells and Schwann cells of the central and peripheral nervous systems as well as in Langerhans cells and cells of the anterior pituitary. S-100a0 $(\alpha \alpha)$, representing $5 \%$ of brain $\mathrm{S}-100$ protein, is predominantly found outside of the nervous system in slow-twitch skeletal muscle, heart and kidney [17].

Elevations of S-100 in CSF and serum have been observed in various forms of acute brain damage after head trauma, cerebral hypoxia, cerebral bleeding, and ischemic stroke $[5,7,8,10,18-20]$ as well as intracranial tumours and infectious injury [21-23]. Because only low levels of this protein are normally present in serum, the presence of S-100 in serum after structural damage to the brain may be due to combined selective leakage out of necrotic glial cells into the CSF and passage through an impaired brainblood barrier. Thus, elevated serum concentration of the $\mathrm{S}-100 \beta \beta$ isomer correlates with proven cerebral injury $[4,20]$.

Brain cells contain a number of glycolytic enzyme enolases, and NSE is defined as the $\gamma \gamma$-isoenzyme subunit. NSE constitutes $\sim 75 \%$ of total enolase subunits. It is predominantly found in neurons, where it is located in the cytoplasm, and at low concentrations in neuroendocrine cells. It is, however, also present in several other tissues [24, 25] and serves as a tumour marker for neuroblastoma and oat-cell carcinoma of the lung [25]. Serum levels of NSE are increased following head injury, infarction, systemic anoxia in humans and various other insults to the central nervous system (CNS) [7-9, 19, 26]. Moreover, because erythrocytes and thrombocytes contain considerable amounts of NSE, haemolysis induced by sample collection may interfere with NSE measurements [24].

$\beta$-trace is a major CSF protein, shown to be structurally, enzymatically, and immunologically identical to prostaglandin-D synthase (PGDS) [27]. PGDS has been localised in the leptomeninges covering the brain surface, spinal cord, and large intracerebral vessels as well as choroid plexus and oligodendrocytes in animals and humans [28]. It serves as a neuromodulator of several central actions in animals such as the sleep-wake-cycle, body temperature and neurotransmitter release [28], and was recently found to be also involved in healthy human sleep regulation [29]. CSF levels of $\beta$-trace are elevated in patients after the onset of stroke [30], and $\beta$-trace could also be detected in the serum of patients with cerebrovascular disease [31], possibly indicating repair processes.

In this study, serial measurements of blood levels of $\mathrm{S}-100 \beta$ protein, NSE and $\beta$-trace protein were evaluated to establish whether they can be used to detect even subtle levels of cerebral injury in SAS patients with normal neurological examination and without a previous history of neurological cerebrovascular events.

\section{Materials and methods}

\section{Study subjects}

The age of the 19 male patients ranged from 32-64 yrs (mean 50.6 yrs). Every patient who participated in the study underwent neurological examination and computed tomography (CT) of the brain on admission. Patients with documented or clinical evidence of brain infarction, haemorrhage, head trauma or CNS infection within 6 months before admission or with a CNS tumour were excluded from the study. None of the patients had a definite history of a previous neurological event like transient ischaemic attack (TIA), prolonged reversible ischaemic neurologic deficit (PRIND) or stroke. All had normal renal function. All subjects were studied in the Sleep Laboratory of the Dept of Psychiatry and Psychotherapy, University Göttingen or in the Sleep Laboratory of the Dept of Pulmology, Evangelic Hospital Göttingen-Weende.

This study was approved by the local Research Ethical Committee and written consent was obtained from each patient.

\section{Study design}

Serum concentrations of NSE, S- $100 \beta$ protein and $\beta$-trace were measured in the evening just before and in the morning immediately after sleep using commercially available assays in SAS patients without neurological symptoms or previous cerebrovascular events. A total of 19 male patients with confirmed SAS were studied. The subjects were divided into patients with sleep apnoea/hypopnoea without severe hypoxaemia during sleep (group 1) and patients with both obstructive sleep apnoea/hypopnoea and severe hypoxaemia during sleep (group 2), based upon an arbitrary cut-off (respiratory disturbance index (RDI) $>40$ episodes $\cdot h^{-1}$ and lowest arterial oxygen saturation $\left(\mathrm{min} S \mathrm{a}, \mathrm{O}_{2}\right)<80 \%$ ). The characterisatics of the subjects are shown in table 1.

\section{Methods}

\section{Sleep analysis}

SAS was diagnosed on both nights by means of overnight polysomnography following international 
Table 1.-Characteristics of sleep apnoea syndrome patients participating in the study

\begin{tabular}{|c|c|c|c|c|c|c|}
\hline Subject no. & Age yrs & $\mathrm{BMI} \mathrm{kg} \cdot \mathrm{m}^{-2}$ & BP $\mathrm{mmHg}$ & RDI & $S_{\mathrm{a}, \mathrm{O}_{2}-\mathrm{I}}$ & $\min S \mathrm{a}, \mathrm{O}_{2} \%$ \\
\hline \multicolumn{7}{|l|}{ Group 1} \\
\hline 1 & 49 & 35.49 & $190 / 120$ & 21.3 & 22 & 80 \\
\hline 2 & 60 & 28.08 & $100 / 70$ & 15.2 & 14.8 & 83 \\
\hline 3 & 52 & 33.74 & $150 / 90$ & 12.8 & 14.3 & 75 \\
\hline 4 & 33 & 27.29 & $115 / 70$ & 17 & 22 & 81 \\
\hline 5 & 62 & 25.47 & $140 / 90$ & 18.4 & 15.3 & 75 \\
\hline 6 & 54 & 40.86 & $130 / 80$ & 19.1 & & 77 \\
\hline 7 & 51 & 24.24 & $130 / 80$ & 19.4 & 20.5 & 83 \\
\hline 8 & 62 & 29.06 & $120 / 80$ & 12.4 & 23.7 & 80 \\
\hline 9 & 36 & 38.16 & $130 / 80$ & 22.3 & 27.9 & 83 \\
\hline 10 & 49 & 23.45 & $135 / 85$ & 22 & & 88 \\
\hline Mean \pm SD & $50.8 \pm 9.9$ & $30.6 \pm 6.1$ & $134 \pm 24 / 84.5 \pm 14.2$ & $18 \pm 3.6$ & $20.1 \pm 4.9$ & $80.5 \pm 4.1$ \\
\hline \multicolumn{7}{|l|}{ Group 2} \\
\hline 1 & 56 & 29.22 & $130 / 80$ & 67 & & 63 \\
\hline 2 & 43 & 47.62 & $170 / 115$ & 111.7 & & 60 \\
\hline 3 & 64 & 37.81 & $150 / 110$ & 49 & 45.8 & 48 \\
\hline 4 & 45 & 36.30 & $140 / 80$ & 64.2 & 38.5 & 65 \\
\hline 5 & 32 & 42.45 & $125 / 80$ & 87.1 & & 64 \\
\hline 6 & 41 & 29.32 & $140 / 90$ & 67.4 & 65.8 & 64 \\
\hline 7 & 46 & 31.28 & $130 / 80$ & 89.1 & & 30 \\
\hline 8 & 62 & 35.76 & $140 / 80$ & 47.8 & & 39 \\
\hline 9 & 64 & 28.08 & $140 / 80$ & 95.2 & 72.1 & 76 \\
\hline Mean \pm SD & $50.3 \pm 11.5$ & $35.3 \pm 6.6$ & $140.6 \pm 13.3 / 88.33 \pm 14.1$ & $75.4 \pm 21.7$ & $55.6 \pm 16$ & $56.6 \pm 14.6$ \\
\hline
\end{tabular}

BMI: body mass index; BP: blood pressure; RDI: respiratory disturbance index; $S_{\mathrm{a}, \mathrm{O}_{2}}$-I: oxygen desaturation index; min $S_{\mathrm{a}}, \mathrm{O}_{2}$ : lowest arterial oxygen saturation.

guidelines using standard methods [32, 33]: standard polysomnography monitored electroencephalogram, right and left electrooculogram, electrocardiogram, submental electromyogram and electromyogram of the anterior tibialis muscle. Respiratory parameters were assessed by measuring nasal and oral airflow through thermistors. Thoracic and abdominal respiratory excursions induced by breathing effort were determined simultaneously with two inductance plethysmograph belts. A finger pulse oximeter (Biox 37003; Ohmeda, Tokyo, Japan) was used to continuously measure arterial oxyhaemoglobin saturation. Body position and movements were detected by infrared video monitoring. All recordings were registered on a polysomnograph (Nihon Kohden, Tokyo, Japan) and stored on a personal computer system.

\section{Laboratory methods}

Blood samples were obtained twice in the evening at 23:00 h shortly before bedtime and immediately in the morning after awakening at 06:00 h. The following analyses were performed in serum: S-100 $\beta$, NSE and $\beta$-trace protein. The assays were performed in a batch including standards and all samples were measured twice. Mean values were considered for further analysis. For S- $100 \beta$ protein, NSE and $\beta$-trace measurement a method that was sensitive enough to detect S-100 $\beta$, NSE and $\beta$-trace levels in healthy control subjects was used.

The serum concentration of $\mathrm{S}-100 \beta$ protein was measured using an immunoluminometric assay

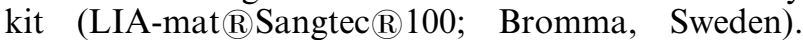

Sangtec100 measures the $\beta$-subunit of the protein S100 as defined by the three monoclonal antibodies SMST 12, SMSK 25 and SMSK 28. For detection and calculation, a luminiscence analyser (Byk Sangtec, Diezenbach, Germany) was used. The detection limit of this assay was $20 \mathrm{pg} \cdot \mathrm{mL}^{-1}$. At $280 \mathrm{pg} \cdot \mathrm{mL}^{-1}$, an intra-assay coeffiecient of variation $(\mathrm{CV})$ of $5.5 \%$ and an interassay $\mathrm{CV}$ of $10.1 \%$ were defined (LIA-mat $\mathbb{R}$ ) Sangtec100 product information). In normal healthy controls, levels of $\mathrm{S}-100 \beta$ in serum are $\leqslant 0.11 \mu \mathrm{g} \cdot \mathrm{L}^{-1}$

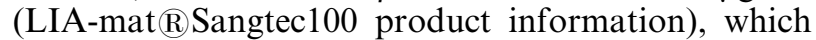
corresponds to the cut-off value established in the present authors laboratory [34].

Serum NSE levels were determined by the Cobas Core NSE enzyme immunoassay (EIA) kit of Hoffmann-La Roche AG (Basel, Switzerland). This solid-phase sandwich EIA uses monoclonal and polyclonal anti-NSE. The normal range of serum NSE in healthy volunteers is $3.3-13.3 \mathrm{ng} \cdot \mathrm{mL}^{-1}$, and the mean \pm SD is $6.9 \pm 2.2 \mathrm{ng} \cdot \mathrm{mL}^{-1}[35]$.

$\beta$-Trace in serum was determined by an immunonephelometric assay (Behringwerke AG, Marburg, Germany) on an automated Behring Nephelometer Analyzer. The test kit employs affinity-purified polyclonal rabbit antibodies coupled to latex particles and is sensitive enough (analytical sensitivity of $0.05 \mathrm{mg} \cdot \mathrm{L}^{-1}$ ) to measure serum concentrations reliably. The validity data of the $\beta$-trace assay have been reported previously [36].

\section{Analysis}

Sleep stages and arousal data were manually determined and appended to the data stored by the 
personal computer system. Evaluation of cardiorespiratory dysfunction included RDI, min $\mathrm{Sa}_{\mathrm{a}} \mathrm{O}_{2}$, desaturation index $\left(\mathrm{S}_{\mathrm{a}}, \mathrm{O}_{2}-\mathrm{I}\right)$ for the entire night and morning arterial blood pressure (BP).

Data are expressed as arithmetic mean \pm SD. The statistical analysis of group and time differences are based on an analysis of variance (ANOVA) with repeated measures for each obtained parameter. Statistical comparison between both groups was also performed using a t-test on a 0.05 level.

\section{Results}

NSE serum concentration in all patients ranged between $3.7-33.6 \mathrm{ng} \cdot \mathrm{mL}^{-1}$. Two patients, one in each group, had increased NSE serum concentrations consistently above the normal range in healthy volunteers. Only two patients with mild SAS showed a rise in the morning compared with the values before sleep.

In 15 patients the serum concentration of $S-100 \beta$ protein was below the detection limit of the assay $\left(0.02 \mu \mathrm{g} \cdot \mathrm{L}^{-1}\right)$. In all patients the serum levels of $\mathrm{S}-100 \beta$ were within the normal range. Only two patients with severe SAS showed a slight rise in morning S-100 $\beta$.

The range of serum $\beta$-trace in SAS was 0.29 $1.32 \mathrm{mg} \cdot \mathrm{L}^{-P}$. In four patients with mild SAS there was an increase of serum $\beta$-trace concentration of $>10 \%$ in the morning, whereas three patients with severe SAS showed a decrease in the morning of $>10 \%$, compared with the values before sleep (table 2).

Serum concentrations of NSE $\left(\mathrm{ng} \cdot \mathrm{mL}^{-1}\right), \mathrm{S}-100 \beta$ $\left(\mu \mathrm{g} \cdot \mathrm{L}^{-1}\right)$, and $\beta$-trace $\left(\mathrm{mg} \cdot \mathrm{L}^{-1}\right)$ were not significantly different, independent of when the blood was taken (before B or after sleep (A)) or the degree of SAS (table 2). There was also no correlation with RDI (rNSE/B=-0.0028, rNSE/A=-0.3081, r $\beta$ trace/ $\mathrm{B}=0.1982$, $\mathrm{r} \beta$ trace/A=0.1517). The relationships between NSE and $\beta$-trace serum concentrations and RDI are shown in figure 1.

However, statistical comparison of $\beta$-trace serum concentration between mild and severe SAS at both times revealed a tendency of higher levels in severe SAS: severe SAS $0.62 \pm 0.33 \mathrm{mg} \cdot \mathrm{L}^{-1}$, in mild SAS $0.45 \pm 0.06 \mathrm{mg} \cdot \mathrm{L}^{-1}(\mathrm{p}=0.06$ in a one-tailed t-test).

\section{Discussion}

In mild and severe SAS patients without neurological symptoms or previous cerebrovascular events, no elevations in serum concentrations of the neuronal marker NSE, the astroglial marker S-100 $\beta$ protein or the meningeal marker $\beta$-trace protein could be found. The structural cerebral brain injury caused by SAS in these patients may be too small to produce a measurable increase in the serum concentration of these markers or subclinical cerebral damage may be positioned outside the lower detection limits of the analytical methods used here. Nevertheless there is a need for biochemical markers of small cerebral injury in SAS and thus more sensitive methods are required for further investigations.

Several CSF markers, including S-100 $\beta$ protein and NSE, may serve as sensitive markers of the extent of brain damage. Studies on CSF concentrations of

Table 2. - Biochemical marker of cerebral injury in mild and severe sleep apnoea syndrome patients just before and after sleep

\begin{tabular}{|c|c|c|c|c|c|c|}
\hline \multirow[t]{2}{*}{ Subject no. } & \multicolumn{2}{|c|}{$\mathrm{NSE} n g \cdot \mathrm{mL}^{-1}$} & \multicolumn{2}{|c|}{$\mathrm{S}-100 \beta$ protein $\mu \mathrm{g} \cdot \mathrm{L}^{-1}$} & \multicolumn{2}{|c|}{$\beta$-trace $\mathrm{mg} \cdot \mathrm{L}^{-1}$} \\
\hline & B & A & B & A & B & A \\
\hline \multicolumn{7}{|l|}{ Group 1} \\
\hline 1 & 17.5 & 14.4 & 0.039 & 0.021 & 0.43 & 0.45 \\
\hline 2 & 9.9 & 25.8 & 0.015 & 0.001 & 0.41 & 0.39 \\
\hline 3 & 10.1 & 10.3 & 0.001 & 0.001 & 0.51 & 0.49 \\
\hline 4 & 9 & 6.4 & 0.001 & 0.001 & 0.42 & 0.48 \\
\hline 5 & 8.8 & 8.7 & 0.003 & 0.003 & 0.40 & 0.48 \\
\hline 6 & 12 & 6.9 & 0.001 & 0.002 & 0.54 & 0.54 \\
\hline 7 & 7.8 & 5.7 & 0.001 & 0.001 & 0.38 & 0.43 \\
\hline 8 & 6.3 & 33.6 & 0.001 & 0.001 & 0.49 & 0.58 \\
\hline 9 & 16.9 & 10.6 & 0.001 & 0.002 & 0.37 & 0.35 \\
\hline 10 & 7.4 & 9 & 0.001 & 0.001 & 0.41 & 0.37 \\
\hline $\operatorname{Mean} \pm \mathrm{sD}$ & $10.6 \pm 3.8$ & $13.1 \pm 9.3$ & $9<\mathrm{DL}^{\#}$ & $9<\mathrm{DL}^{\#}$ & $0.44 \pm 0.06$ & $0.46 \pm 0.07$ \\
\hline \multicolumn{7}{|l|}{ Group 2} \\
\hline 1 & 5.2 & 3.7 & 0.001 & 0.001 & 0.53 & 0.46 \\
\hline 2 & 11.4 & 11.7 & 0.017 & 0.001 & 0.38 & 0.38 \\
\hline 3 & 6.5 & 5.9 & 0.011 & 0.026 & 0.47 & 0.46 \\
\hline 4 & 15.3 & 14 & 0.028 & 0.006 & 0.36 & 0.34 \\
\hline 5 & 16.6 & 8.7 & 0.001 & 0.001 & 0.50 & 0.47 \\
\hline 6 & 13.9 & 7.7 & 0.001 & 0.001 & 0.98 & 1.05 \\
\hline 7 & 5.3 & 7.4 & 0.002 & 0.001 & 0.31 & 0.28 \\
\hline 8 & 4.7 & 7.9 & 0.028 & 0.032 & 1.32 & 1.11 \\
\hline 9 & 7.3 & 7.7 & 0.012 & 0.005 & 0.90 & 0.88 \\
\hline Mean \pm SD & $9.6 \pm 4.7$ & $8.3 \pm 3.0$ & $7<\mathrm{DL}^{\#}$ & $7<\mathrm{DL}^{\#}$ & $0.4 \pm 0.35$ & $0.60 \pm 0.32$ \\
\hline
\end{tabular}

NSE: neuron-specific enolase; B: before sleep; A: after sleep; ${ }^{\#}$ : number of samples below the detection limit of the assay $\left(0.02 \mu \mathrm{g} \cdot \mathrm{L}^{-1}\right)$. 

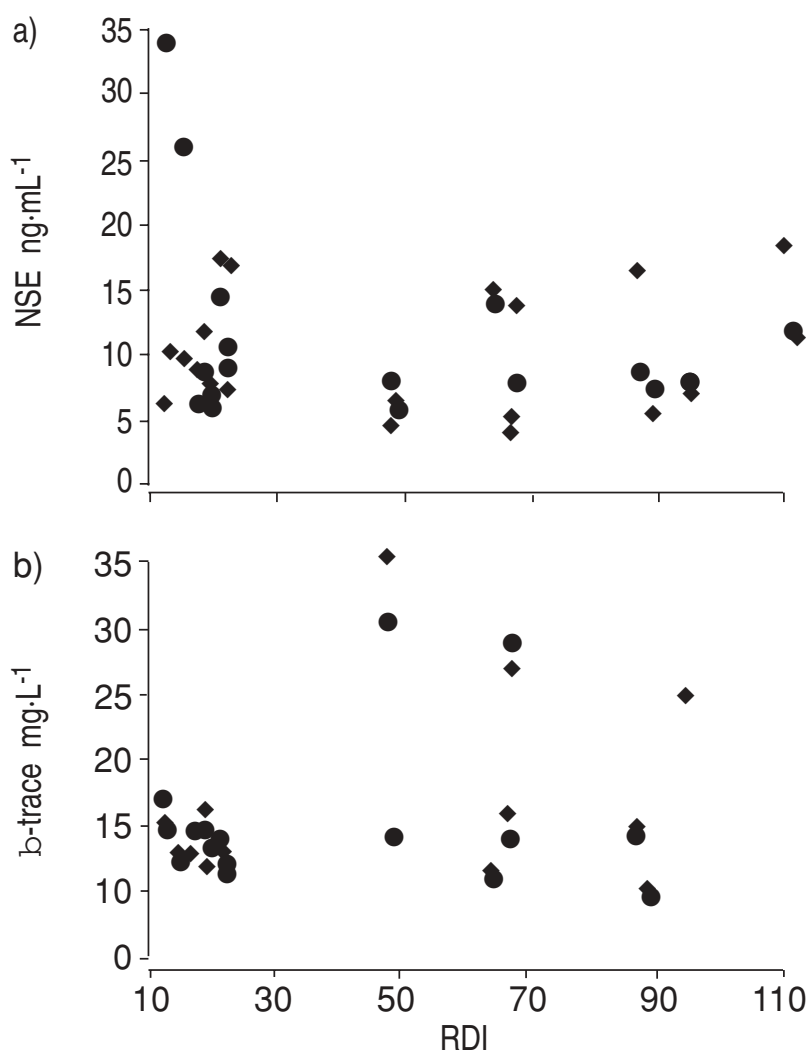

Fig. 1.-Relationship between biochemical markers of cerebral injury. a) Neuron-specific enolase (NSE) and b) $\beta$-trace and severity of sleep apnoea syndrome according to the respiratory disturbance index (RDI) according to the time of blood sampling. $\diamond$ : before sleep; $\boldsymbol{O}$ : after sleep.

$\mathrm{S}-100 \beta$ protein and NSE in patients with neurological lesions have indicated a quantitative relationship between the degree of cell damage in the CNS and concentration of these proteins in CSF [8, 10, 18]. Clinically, increased levels of NSE have been found soon after ischaemic stroke in CSF and blood, and elevated concentrations of S-100 protein have been reported in CSF and serum of the majority of patients with ischaemic stroke, intracerebral haemorrhage and subarachnoid haemorrhage $[7,8,20,37]$. There are also reports that higher NSE levels in serum correlate with large infarct volume [9]. Compared with control subjects, patients who had suffered acute cerebral infarction had clearly elevated blood levels of S-100 and NSE.

With regard to small structural brain damage, only a slight increase of CSF S- $100 \beta$ in patients with small infarcts [4] or no increase of S-100 levels in CSF after transient ischaemic attack and minor stroke [8] have been reported. In addition, S-100 protein in serum was not measureable in any of the patients with small subcortical infarct [6]. However, increased serum concentrations of S-100 protein have been detected in $20 \%$ of the samples drawn within the first hours from patients with isolated minor head injury [38] and serum S-100 protein has been measured in healthy controls [7, 39]. These differing results may be attributed to different lower detection limits of the analytical methods used to measure S-100 protein in blood. After small infarcts and transient ischaemic attacks an increase of NSE could be shown [8]. An increase of NSE has also been found in patients with minor head injury [9]. There is no evidence that other risk factors for stroke, such as diabetes mellitus or hypertension as well as subject age or sex, influence the blood levels of S-100 or NSE [7].

Because of the lack of specifity for cerebral infarction, the biochemical markers investigated cannot exclusively be regarded as a diagnostic tool for cerebral ischaemia but they do indicate any cell damage in the CNS. Therefore, the current authors believe that the combination of the results of two or more markers may improve their usefulness and reliability. Another reason for analysing these markers is the possibility of differentiating between gray and white matter damage, as $\mathrm{S}-100 \beta$ is present mainly in glial cells and NSE mainly in neurons [23], whereas $\beta$-traces serves as a meningeal marker.

Although there may be several mechanisms by which sleep apnoea increases the risk of stroke, the most important is the increasing prevalence of atherosclerosis with occult cerebrovascular disease as well as an increased risk of embolisation and marked haemodynamic changes in cerebral perfusion. Assuming that TIA represents only a mild form of recognisable cerebral ischaemia, one aim of this study was to investigate if structural brain damage occurs in SAS patients without history of previous TIA, PRIND or stroke using peripheral markers of ischemic focal brain damage. SAS patients with persistent neuropsychological deficits, despite an appropriate noncontinuous positive airway pressure treatment, were also excluded from this study to avoid mingling with possible brain injury of any other origin than SAS.

Because of recurrent disturbances of breathing during sleep with consecutive hypoxaemia and possible cerebral injury, no restoration of astroglial or neuron integrity can be assumed in untreated severe SAS. In particular, the proportional increase in rapid eye movement sleep in the morning regularly corresponds with an increase in respiratory disturbances. Thus, taking blood in the morning immediately after sleep within the biological half-life of the markers studied seemed an appropriate method for detecting any damage of cerebral tissue. The half-life time of

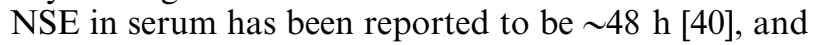
therefore blood levels of NSE would be expected to rise as long as infarct damage continued and NSE was washing out of brain tissue. Plasma S-100ao is eliminated by the kidney with a biological half-life of $\sim 2 \mathrm{~h}$ [41]. Thus, an elevated serum concentration must be maintained by persistent release. An increase of $\mathrm{S}-100 \beta$ protein with time suggests a progressive release of S-100 into the circulation through a less reversible disruption of the blood-brain barrier.

Urinary collection and measurement of biochemical markers might be a useful method for detecting subtle changes, but is limited in SAS because of renal dysfunction [15]. The primary renal excretion of S-100 protein will allow measurements to be taken 
from overnight or morning urine, but first this approach has to be established.

In the SAS patients in this study only serum values of the biochemical markers studied within the normal range could be found independently of the time that blood was taken. There was also no preponderance of any of these markers in SAS, which would differentiate between gray and white matter or meningeal damage. Therefore it is to be expected that only definite neuronal infarction including at least the partial destruction of the penumbra will result in an increase of extracellular S-100 $\beta$, NSE or $\beta$-trace. Leakage of glial cells or neurons has to be accompanied by a functional impairment of the blood-CSF barrier to allow the transport of S-100 $\beta$ and NSE from brain tissue into the vascular compartment. The infarct size also markedly influences the release of S-100 $\beta$ and NSE and it is possible that structural cerebral injury causeed by SAS is too small to produce a measureable increase in serum $S-100 \beta$ protein or NSE. Subclinical cerebral injuries may also be positioned outside the lower detection limits of the used analytical methods used. Conversely, as the patients studied had no neurological signs or symptoms they may have no small structural brain damage.

Another aspect of this study was a tendency of increased serum PGDS in severe SAS, which is known to be associated with hypersomnia. PGDS is involved in human sleep regulation [29], and several diseases with hypersomnia like Trypanosoma induced sleeping sickness, systemic mastocytosis, major depression or bacterial meningitis, showed changes in the enzyme PGDS or its product prostaglansin $\mathrm{D}_{2}$ in different body fluids $[28,36]$. Therefore, further investigations concerning the role of PGDS in hypersomnia are necessary.

Independent of the low detection limits, the measurement of S-100 $\beta$, neuron-specific enolase, and $\beta$-trace protein concentration in blood did not appear to be a useful method for detecting individual risk of stroke and monitoring the effects of treatment in sleep apnoea patients. Further investigations are required, especially in subjects with undeniable small brain damage such as transient ischemic attack or vascular dementia and in sleep apnoea syndrome, by means of other probably more sensitive methods such as indices of oxidative stress or urinary indices. Nevertheless there is a need for biochemical markers of small cerebral injury in sleep apnoea syndrome. A noninvasive biochemical marker would be of particular value in clinical practice, to screen for small diffuse brain damage, to show the eventual extent of cerebral injury and to monitor progression and/or efficiacy of therapy.

\section{References}

1. Pressman MR, Schetman WR, Figueroa WG, Van Uitert B, Caplan HJ, Peterson DD. Transient ischemic attacks and minor stroke during sleep. Relationship to obstructive sleep apnea syndrome. Stroke 1995; 26: 2361-2365.

2. Palomäki H, Partinen M, Erkinjuntti T, Kaste M.
Snoring, sleep apnea syndrome, and stroke. Neurology 1992; 42: Suppl. 6, 75-82.

3. Decary A, Rouleau I, Montplaisir J. Cognitive deficits associated with sleep apnea syndrome: a proposed neuropsychological test battery. Sleep 2000; 23: 369-381.

4. Aurell A, Rosengren LE, Karlsson B, Olsson JE, Zbornikova V, Haglid KG. Determination of S-100 and glial fibrillary acidic protein concentrations in cerebrospinal fluid after brain infarction. Stroke 1991; 22: $1254-1258$.

5. Büttner T, Weyers S, Postert T, Sprengelmeyer R, Kuhn W. S-100 Protein: Serum marker of focal brain damage after ischemic territoial MCA infarction. Stroke 1997; 28: 1961-1965.

6. Kim JS, Yoon SS, Kim YH, Ryu JS. Serial Measurement of interleukin-6, transforming growth factor- $\beta$, and S-100 protein in patients with acute stroke. Stroke 1996; 27: 1553-1557.

7. Missler U, Wiesmann M, Friedrich C, Kaps M. S-100 Protein and neuron-specific enolase concentrations in blood as indicators of infarction volume and prognosis in acute ischemic stroke. Stroke 1997; 28: 1956-1960.

8. Persson L, Hardemark HG, Gustafsson J, et al. S-100 protein and neuron-specific enolase in cerebrospinal fluid and serum: markers of cell damage in human central nervous system. Stroke 1987; 18: 911-918.

9. Skogseid IM, Nordby HK, Urdal P, Paus E, Lilleaas $F$. Increased serum creatine kinase $B B$ and neuron specific enolase following head injury indicates brain damage. Acta Neurochir (Wien) 1992; 115: 106-111.

10. Hardemark HG, Ericsson N, Kotwica Z, et al. S-100 protein and neuron-specific enolase in CSF after experimental traumatic or focal ischemic brain damage. J Neurosurg 1989; 71: 727-731.

11. Kruse A, Cesarini KG, Bach FW, Persson L. Increases of neuron-specific enolase, S-100 protein, creatine kinase and creatine kinase BB isoenzyme in CSF Following intraventricular catheter implantation. Acta Neurochir (Wien) 1991; 110: 106-109.

12. Findley LJ, Boykin M, Fallon $\mathrm{T}$, Belardinelli $\mathrm{L}$. Plasma adenosine and hypoxemia in patients with sleep apnea. J Appl Physiol 1988; 64: 556-561.

13. Weigand MA, Michel A, Eckstein HH, Martin E, Bardenheuer HJ. Adenosine: a sensitive indicator of cerebral ischaemia during carotid endarterectomy. Anesthesiolgy 1999; 91: 414421.

14. Chin K, Ohi M, Shimizu K, et al. Increase in bilirubin levels of patients with obstructive sleep apnea in the morning - a possible explanation of induced heme oxygenase-1. Sleep 2001; 24: 218-223.

15. Ehlenz K, Firle K, Schneider H, et al. Reduction of nocturnal diuresis and natriuresis during treatment of obstructive sleep apnea (OSA) with nasal continuous positive air pressure (nCPAP) correlates to cGMP excretion. Med Klin 1991; 86: 294-296.

16. Johnsson P. Markers of cerebral ischemia after cardiac surgery. J Cardiothorac Vasc Anesth 1996; 10: $120-126$.

17. Fano G, Biocca S, Fulle S, Mariggio MA, Belia S, Calissano P. The S-100: a protein family in search of a function. Prog Neurobiol 1995; 46: 71-82.

18. Hardemark HG, Almqvist O, Johansson T, Pahlman S, Persson L. S-100 protein in cerebrospinal fluid after aneurysmal subarachnoid haemorrhage: relation to functional outcome, late CT and SPECT changes, and 
signs of higher cortical dysfunction. Acta Neurochir (Wien) 1989; 99: 135-144.

19. Rosen H, Rosengren L, Herlitz J, Blomstrand C. Increased serum levels of the $\mathrm{S}-100$ protein are associated with hypoxic brain damage after cardiac arrest. Stroke 1998; 29: 473-477.

20. Wiesmann M, Missler U, Hagenström H, Gottmann D. S-100 protein plasma levels after aneurysmal subarachnoid haemorrhage. Acta Neurochir (Wien) 1997; 139: 1155-1160.

21. Fagnart OC, Sindic CJM, Laterre C. Particle counting immunoassay of S100 protein in serum. Possible relevance in tumors and ischemic disorders of the central nervous system. Clin Chem 1988; 34: 1387-1391.

22. Michetti F, Massaro A, Russo G, Rigon G. The S-100 antigen in cerebrospinal fluid as a possible index of cell injury in the nervous system. J Neurol Sci 1980; 44: 259-263.

23. Mokuno K, Kato K, Kawai K, Matsuoka Y, Yanagi T, Sobue I. Neuron-specific enolase and S-100 protein levels in cerebrospinal fluid of patients with various neurological diseases. J Neurol Sci 1983; 60: 443-451.

24. Ghobrial M, Ross ER. Immunocytochemistry of neuron-specific enolase: a re-evaluation. In: Zimmerman HM, ed. Progress in Neuropathology. New York, Raven Press, 1986; pp. 199-221.

25. Marangos PJ, Schmechel DE. Neuron specific enolase, a clinically useful marker for neurons and neuroendocrine cells. Ann Rev Neurosci 1987; 10: 269-295.

26. Cunningham RT, Young IS, Winder J, et al. Serum neurone specific enolase (NSE) levels as an indicator of neuronal damage in patients with cerebral infarction. Eur J Clin Invest 1991; 21: 497-500.

27. Watanabe K, Urade Y, Mäder M, Murphy C, Hayaishi O. Identification of beta-trace as prostaglandin D synthase. Biochem Biophys Res Commun 1994; 203: 1110-1116.

28. Urade Y, Hayaishi O. Prostaglandin $\mathrm{D}_{2}$ and sleep regulation. Biochim Biophys Acta 1999; 1436: 606-615.

29. Jordan W, Rodenbeck A, Hajak G, Cohrs S, Tumani H. Prostaglandin D synthase in human sleep-wake regulation (abstract). Abstracts Vol II, XI World Congress of Psychiatry, 1999; 112.

30. Link H, Olsson JE. Beta-trace protein concentration in CSF in neurological disorders. Acta Neuro Scand 1972; 48: 57.
31. Melegos DN, Freedman MS, Diamandis EP. Prostaglandin D synthase concentration in cerebrospinal fluid and serum of patients with neurological disorders. Prostaglandins 1997; 54: 463-474.

32. American Thoracic Society. Indications and standards for cardiopulmonary sleep studies. Am Rev Respir Dis 1989; 139: 559-567.

33. Rechtschaffen A, Kales A. A manual for standardized terminology, techniques and scoring system for sleep stages of human subjects. Washington DC, Public Health Service, US Government Printing Office, 1968; pp. $1-12$.

34. Wiltfang $\mathbf{J}$, Nolte $\mathbf{W}$, Otto $\mathbf{M}$, et al. Elevated serum levels of astroglial $\mathrm{S} 100 \beta$ in patients with liver cirrhosis indicate early and subclinical portal-systemic encephalopathy. Metab Brain Dis 1999; 14: 239-251.

35. Tumani $\mathrm{H}$, Otto $\mathrm{M}$, Gefeller $\mathrm{O}$, et al. Kinetics of serum neuron-specific enolase and prolactin in patients after single epileptic seizures. Epilepsia 1999; 40: 713-718.

36. Tumani H, Reiber H, Nau R, et al. Beta-trace protein concentration in cerebrospinal fluid is decreased in patients with bacterial meningitis. Neurosci Lett 1998; 242: 5-8.

37. Persson L, Hardemark H, Edner G, Ronne E, Mendel-Hartvig I, Pahlman S. S-100 protein in cerebrospinal fluid of patients with subarachnoid haemorrhage: a potential marker of brain damage. Acta Neurochir (Wien) 1988; 93: 116-122.

38. Ingebrigtsen T, Romner B, Kongstad P, Langbakk B. Increased serum concentrations of protein S-100 after minor head injury: a biochemical marker with prognostic value? J Neurol Neurosurg Psychiatry 1995; 59: 103-104.

39. Missler U, Wiesmann M. Measurement of S-100 protein in human blood and cerebrospinal fluid: analytical method and preliminary clinical results. Eur J Clin Chem Clin Biochem 1995; 33: 743-748.

40. Ishiguro Y, Kato K, Ito T, Nagaya M, Yamada N, Sugito T. Nervous system-specific enolase in serum as a marker for neuroblastoma. Pediatrics 1983; 72 : 696-700.

41. Usui A, Kato K, Abe T, Murase M, Tanaka M, Takeuchi E. S-100ao protein in blood and urine during open-heart surgery. Clin Chem 1989; 35: 1942-1944. 